\title{
CALCIUM IONS AND CONTROL OF THE MOTILITY OF SEA URCHIN SPERMATOZOA
}

\author{
L. G. YOUNG AND L. NELSON* \\ Department of Physiology, Emory University, Atlanta, Georgia 30322, and \\ *Department of Physiology, Medical College of Ohio, Toledo, Ohio 43614, and \\ Marine Biological Laboratory, Woods Hole, Massachusetts 02543, U.S.A.
}

(Received 1st March 1974)

\begin{abstract}
Summary. Both excess and insufficient calcium ions in the medium adversely affected the swimming performance of sea urchin spermatozoa. Sperm cells suspended in calcium-free artificial sea water swam at less than half the speed of those suspended in artificial sea water containing the optimum of $9 \mathrm{mmol} \mathrm{CaCl}_{2} / \mathrm{l}$. Excess $\mathrm{Ca}^{2+}$ added to natural sea water decreased motility by $20 \%$ at $36 \mathrm{~mm}$ (four times the normal amount) while the same amount of $\mathrm{CaCl}_{2}$ in artificial sea water depressed motility by $45 \%$. The chelating agent, EGTA, caused greater depression than equivalent amounts of EDTA, though at millimolar concentration or higher both caused complete cessation of motility with the flagella in a rigidly extended position. If $\mathrm{LaCl}_{3}$ was added to artificial sea water containing $9 \mathrm{mM}^{-\mathrm{CaCl}_{2}}$, it caused an even greater depression of motility. The effects were detectable at $50 \mathrm{nmol} \mathrm{LaCl}_{3} / 1$ and complete inhibition occurred at $20 \mu \mathrm{mol} / \mathrm{l}$. The flagella ceased beating in a coiled seemingly 'relaxed' state. Sperm motility appears to require maintenance of $\mathrm{Ca}^{2+}$ gradients, reversible sequestration and release of $\mathrm{Ca}^{2+}$, and $\mathrm{Ca}^{2+}$-dependent metabolic regulation of the flagellar contractile system.
\end{abstract}

\section{INTRODUCTION}

Changing patterns of sperm cell metabolism and motility usually reflect changes in the environmental condition. Heavy metal ions and sulphydryl reagents influence the duration and speed of swimming as well as respiration and glycolysis. There have been occasional reports that calcium ions also adversely affect mammalian sperm cell activity. Lardy \& Phillips (1943) found that an increase in the calcium content of the suspension medium inhibited the respiration and glycolysis of bull spermatozoa. Quinn, White \& Voglmayr (1970) recently reported that an excess of extracellular calcium was inhibitory to the motile activity of ram spermatozoa. Bredderman \& Foote (1971), using cell volume as an index, found that excess calcium caused 
both structural and permeability changes in bovine spermatozoa. McGrady \& Nelson (1972) observed that excess calcium in the diluent reversed the polarity of the bull sperm cell membrane potentials from negative inside to positive inside.

A considerable amount is known about the effects of heavy metal ions on the respiration, glycolysis and motility of the spermatozoa of invertebrates (Barron, Nelson \& Ardao, 1948; Rothschild \& Tuft, 1950; Rothschild \& Tyler, 1954; Young \& Nelson, 1974), but there are relatively few data available on the effect of calcium ions on the activity of these spermatozoa. While Tyler (1953) reported that changes in the concentration of external calcium had no effect on the metabolism of Strongylocentrotus purpuratus spermatozoa, he did not investigate the effect of calcium ions on their motility.

In this study, the effects of alterations in the concentration of environmental calcium ions on the motile activity of Arbacia punctulata spermatozoa have been examined.

\section{MATERIALS AND METHODS}

Male Arbacia punctulata were induced to spawn by injection of isotonic $\mathrm{KCl}$ $(0.53 \mathrm{M})$ into the perivisceral cavity. The shed spermatozoa were collected under filtered sea water, centrifuged in a clinical centrifuge for $3 \mathrm{~min}$ at $1000 \mathrm{~g}$ and the supernatant fluid was discarded. The packed spermatozoa were kept at $4^{\circ} \mathrm{C}$ and were used within $4 \mathrm{hr}$ of collection. Immediately before the motility rating tests, samples of the spermatozoa were adjusted to a final concentration of $10^{7} \pm 10 \%$ spermatozoa $/ \mathrm{ml}$ (optical density of 0.500 at $540 \mathrm{~nm}$ ).

A $5-\mathrm{ml}$ vol. of a suspension of spermatozoa in artificial sea water (ASW) was added to each of several round colorimeter tubes containing either: (1) $0.5 \mathrm{ml}$ distilled water or $0.5 \mathrm{ml}$ of $90 \mathrm{~mm}-\mathrm{CaCl}_{2}$, (2) $0.5 \mathrm{ml}$ of $1 \%$ formaldehyde to kill the cells, or (3) $0.5 \mathrm{ml}$. of the reagent being tested. The tube contents were mixed thoroughly by inverting twice.

The swimming speed of spermatozoa, linearly orientated in a mild centrifugal field $(120 \mathrm{~g})$, was determined by measuring the change in optical density and correcting for the sedimentation of the formalin-killed cells (Nelson, 1972). All experimental procedures were carried out in an air-conditioned room $\left(22\right.$ to $\left.23^{\circ} \mathrm{C}\right)$ and initial swimming speeds were obtained within $5 \mathrm{~min}$ of dilution of the spermatozoa.

Unbuffered calcium-free ASW (Cavanaugh, 1956) obtained from the chemical room of the Marine Biological Laboratory (MBL) was buffered with $0.18 \mathrm{mg} \mathrm{NaHCO} / 1$ immediately before use, except when lanthanum chloride was included in the experimental medium.

The MBL calcium-free artificial sea water contained (per litre) $25.55 \mathrm{~g}$ $\mathrm{NaCl}$, $9.0 \mathrm{mmol} \mathrm{KCl}, 22.94 \mathrm{mmol} \mathrm{MgCl}_{2}$ and $25.50 \mathrm{mmol} \mathrm{MgSO}_{4}$, and $0 \cdot 18$ $\mathrm{mg} \mathrm{NaHCO} / \mathrm{l}$ was added just before use. The reagents tested included calcium chloride $\left(\mathrm{CaCl}_{2}\right), 0$ to $36 \mathrm{~mm}$; lanthanum chloride $\left(\mathrm{LaCl}_{3}\right.$, obtained from $\mathrm{K}$ \& K Laboratories, Inc., Plainview, New York), $50 \mathrm{~nm}$ to $100 \mu \mathrm{M}$; ethylenediamine tetraacetic acid (EDTA) disodium salt (Sigma Chemical Co.), $0 \cdot 1$ $\mathrm{mm}$ to $4.5 \mathrm{~mm}$; ethyleneglycol-bis ( $\beta$-amino-ethyl ether) $\mathrm{N}, \mathrm{N}^{\prime}$-tetraacetic acid 
(EGTA) (Sigma Chemical Co.), 0.1 to $4.5 \mathrm{~mm}$. The solutions of EDTA and EGTA were adjusted with $\mathrm{NaOH}$ so that a $1: 10$ dilution in filtered sea water gave a final $\mathrm{pH}$ of $7 \cdot 8$. Suspensions of the spermatozoa were observed with an American Optical Phase-Star microscope at a magnification of $\times 400$.

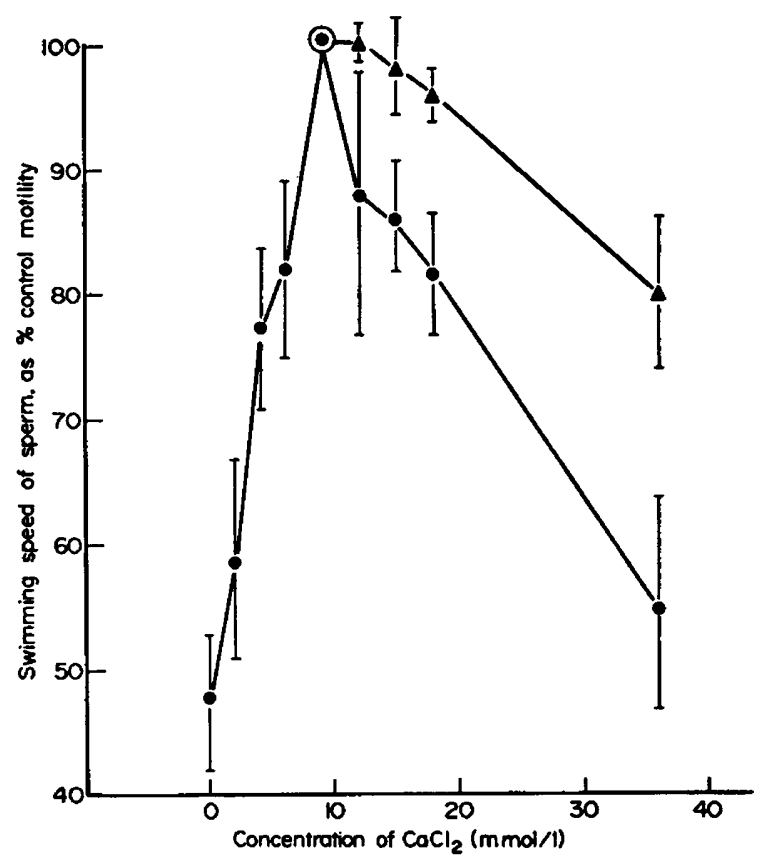

TexT-FIG. 1. The effect of $\mathrm{CaCl}_{2}$ on the swimming speed of Arbacia punctulata spermatozoa. The $\mathrm{CaCl}_{2}$ was added to (O) $\mathrm{Ca}^{2+}$-free artificial sea water (Marine Biological Laboratory, Woods Hole) or to (A) filtered 'natural' sea water from Woods Hole containing $10^{7}$ $\pm 10 \%$ spermatozoa/ml. The points and ranges represent the mean and standard deviations of individual determinations made on spermatozoa collected from a minimum of four individual sea urchins. The temperature was 22 to $23^{\circ} \mathrm{C}$.

\section{RESULTS}

\section{Calcium chloride}

The importance of calcium ions for the motility of Arbacia punctulata spermatozoa became evident as the concentrated sperm cells were diluted into buffered $\mathrm{Ca}^{2+}$-free ASW to which various amounts of $\mathrm{CaCl}_{2}$ were added. Since Woods Hole sea water contains approximately $9 \mathrm{~mm}$ calcium ions (Cavanaugh, 1956), the swimming speed of the spermatozoa in ASW containing this concentration of $\mathrm{Ca}^{2+}$ was referred to as the control motility.

Text-figure 1 shows the motile activity of sea urchin spermatozoa suspended in bicarbonate-buffered ASW which had been brought to $\mathrm{CaCl}_{2}$ concentrations ranging from 0 to $36 \mathrm{mmol} / \mathrm{l}$. After incubation for $10 \mathrm{~min}$ in the medium with no added calcium, the swimming speed of the spermatozoa was half that of spermatozoa incubated in ASW containing $9 \mathrm{mmol} \mathrm{CaCl}{ }_{2} / 1$ for an equal 
period of time. As the concentration of $\mathrm{Ca}^{2+}$ was increased, the rate of movement increased and reached a maximum when the concentration of calcium was $9 \mathrm{~mm}$. Further additions of $\mathrm{CaCl}_{2}$ to the ASW resulted in a gradual decline in motility and in the presence of $36 \mathrm{~mm} \mathrm{Ca}^{2+}$, four times that of the control samples, the swimming speed fell to $55 \%$ of the control values. The $\mathrm{pH}$ ranged from 6.67 (in $\mathrm{Ca}^{2+}$-free) to 6.74 in the presence of $36 \mathrm{~mm}-\mathrm{CaCl}_{2}$.

The \% control motility of spermatozoa exposed to various $\mathrm{CaCl}_{2}$ concentrations did not materially alter when the period of incubation was increased from 10 to $25 \mathrm{~min}$.

The motility of spermatozoa suspended in filtered sea water to which excess calcium ions were added was compared with that of spermatozoa in ASW (Text-fig. 1). Increasing the $\mathrm{Ca}^{2+}$ level of the 'natural' filtered sea water to final concentrations of 12 or $15 \mathrm{mmol} / \mathrm{l}$ had no significant effect on the motility of the spermatozoa which continued to swim at or near control rates. Although the swimming speed of the spermatozoa declined with further increases in the $\mathrm{Ca}^{2+}$ concentration of the filtered sea water, the motility declined less abruptly than when the sperm cells were suspended in ASW containing equivalent amounts of calcium. Doubling the $\mathrm{Ca}^{2+}$ ion concentration of filtered sea water to $18 \mathrm{~mm}$ caused a negligible decrease of $4 \%$ in sperm motility compared to

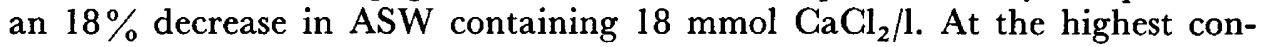
centration of calcium chloride tested $(36 \mathrm{~mm})$, the swimming speed of spermatozoa in filtered sea water decreased by $20 \%$ while in ASW, the motility decreased by $45 \%$ below the control rate. (Filtered sea water varied by no more than $\pm 0.04 \mathrm{pH}$ units on addition of the $\mathrm{CaCl}_{2}$.)

\section{EGTA and EDTA}

To determine the extent to which changes in sperm motility could be related directly to changes in environmental calcium, EGTA was used to lower the calcium ion concentration of filtered sea water. Text-figure 2 shows the response of the sea urchin spermatozoa in filtered sea water containing 0.1 to $4.5 \mathrm{mmol}$ EGTA/l. In concentrations of EGTA up to $0.3 \mathrm{~mm}$, motility declined relatively slowly, but increasing the concentration of EGTA from $0.3 \mathrm{~mm}$ to $0.5 \mathrm{~mm}$ decreased the swimming speed from $60 \%$ to $30 \%$ of the control motility. Further small increments of EGTA caused further decrease in swimming speed and motile activity had virtually ceased in 4.5 mM-EGTA. Examination of the Arbacia spermatozoa under phase-contrast microscopy revealed that the spermatozoa were completely immotile and the flagella were rigidly extended. There was no agglutination of the spermatozoa, but attempts to restore motility to the immobilized spermatozoa by the addition of calcium ions following treatment with EGTA were unsuccessful.

The motile activity of the spermatozoa remained consistently higher in EDTA than in EGTA at all the concentrations of the chelating agents tested at less than $1 \mathrm{~mm}$ (Text-fig. 2). In $0.5 \mathrm{mmol} / 1$, the swimming speed was measured at $65 \%$ of the control values in EDTA while in EGTA, spermatozoa collected from the same sea urchin swam at only $13 \%$ of the control speed. Both EDTA and EGTA were equally effective in abolishing sperm motility in concentrations in excess of $1 \mathrm{mmol} / \mathrm{l}$. 


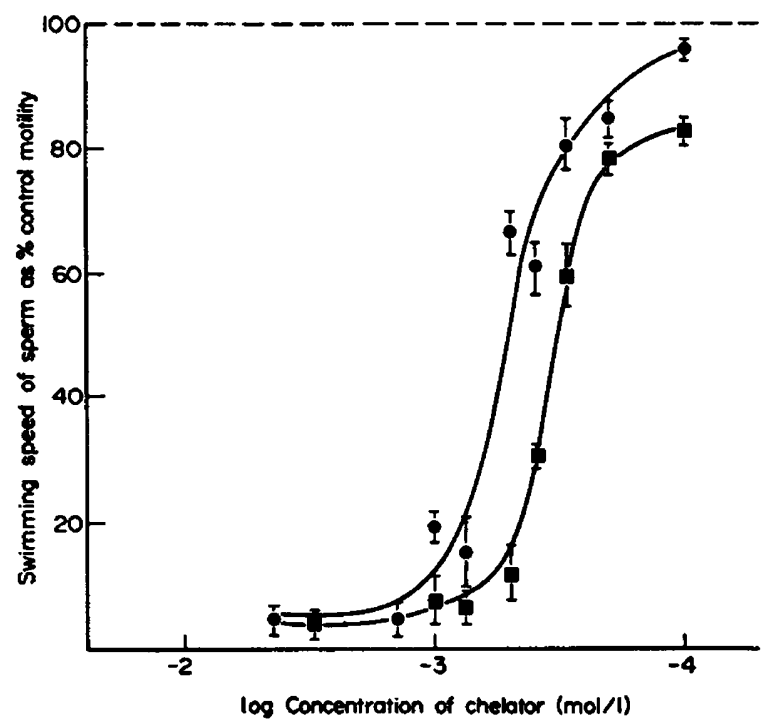

TEXT-FIG. 2. The effect of EGTA and EDTA on the swimming speed of Arbacia punctulata spermatozoa. The EGTA (ם) or EDTA (O) was added to filtered Woods Hole sea water containing $10^{7} \pm 10 \%$ spermatozoa/ml. The broken line represents the $\mathrm{Ca}^{2+}$ content of Woods Hole sea water. The points and ranges represent the mean and standard deviations of separate determinations made on spermatozoa collected from at least three individual sea urchins. The temperature was 22 to $23^{\circ} \mathrm{C}$.

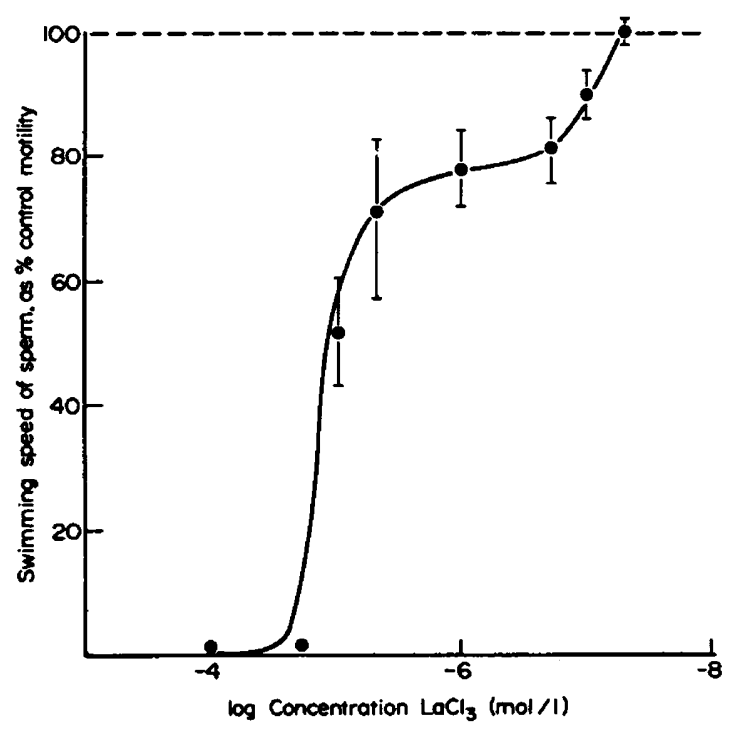

TEXT-FIG. 3. The effect of $\mathrm{LaCl}_{3}$ on the swimming speed of Arbacia punctulata spermatozoa. The $\mathrm{LaCl}_{3}$ was added to artificial sea water (Marine Biological Laboratory, Woods Hole) containing $9 \mathrm{~mm}-\mathrm{CaCl}_{2}$ and $10^{7} \pm 10 \%$ spermatozoa/ml. The broken line represents the $\mathrm{Ca}^{2+}$ content of Woods Hole sea water. The points and ranges represent the mean and standard deviations of separate determinations made on spermatozoa collected from a minimum of four individual sea urchins. The temperature was 22 to $23^{\circ} \mathrm{C}$. 


\section{Lanthanum chloride}

To determine the extent to which calcium conductance may be involved in regulation of sperm motility, spermatozoa were suspended in solutions of unbuffered ASW containing $9 \mathrm{~mm}-\mathrm{CaCl}_{2}$ and various concentrations of $\mathrm{LaCl}_{3}$ from $50 \mathrm{~nm}$ to $100 \mathrm{~mm}$. No bicarbonate was added to the ASW in these experiments in order to avoid precipitation of the lanthanum. (The $\mathrm{pH}$ varied between 6.44 and 6.36 over a concentration range of $10^{-4}$ to $10^{-8} \mathrm{M}-\mathrm{LaCl}_{3}$.) Text-figure 3 shows the \% control swimming speed plotted against lanthanum ion concentration. Swimming speed decreased with increased $\mathrm{La}^{3+}$ con-

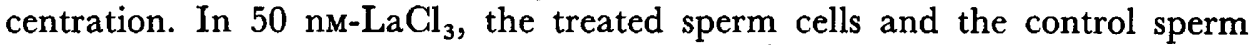
cells swam at the same speed, while $10 \mu \mathrm{M}-\mathrm{La}^{3+}$ decreased motility to $52 \%$ of the control value. At a lanthanum concentration of $20 \mu \mathrm{mol} / \mathrm{l}$, motility ceased entirely. Microscopic examination of the immotile Arbacia spermatozoa showed large numbers of spermatozoa clumped together tail-to-tail with many of the flagella coiled around one another.

\section{DISCUSSION}

Calcium is essential for the maintenance of normal membrane permeability of a variety of cells (Manery, 1969; Miledi, 1971), is intimately involved in the control of contractile processes (Heilbrunn \& Wiercinski, 1947; Ebashi, 1972) and is important in the regulation of cell metabolism (Lardy \& Phillips, 1943; Quinn et al., 1970). Extracellular calcium is responsible for modulation of ciliary movement in Paramecium aurelia (Kung \& Naitoh, 1973) and plays a similar rôle for the ciliated epithelial cells in the oviduct of Necturus maculosus (Murakami \& Eckert, 1972). These investigators suggest that calcium acts indirectly on one or more steps in the pathway of energy metabolism; membrane stimulation increases the intracellular calcium concentration.

The motile activity of sea urchin spermatozoa also depends critically on the concentration of environmental calcium ions. In these experiments on motility effects alone, we have not attempted to specify directly whether calcium exerts its influence at the membrane, on the glycolytic enzymes, or on the contractile apparatus itself. Since $\mathrm{Mg}^{2+}$ and ATP will reactivate 'demembranated' spermatozoa (Brokaw \& Benedict, 1968) it seems fair to conclude that the contractile apparatus cannot by itself respond to the calcium treatments in the manner observed. The cell membrane (Manery, 1969; Miledi, 1971) or the metabolic machinery (Lardy \& Phillips, 1943; Quinn et al., 1970) of the cell must also contribute to these results.

Sea urchin spermatozoa exhibit a monophasic response to increases in the calcium ion above the usual environmental concentration while sperm cells suspended in calcium-free ASW swim at approximately half the rate of control spermatozoa. This may be partly attributed to the fact that dilution into a calcium-free medium provokes the loss of calcium ions from sites on the surface of the spermatozoa which are essential not only for membrane integrity but for maintenance of calcium gradients between the sperm cell surface and the interior. When calcium is added to calcium-free ASW, motility increases to a maximum in $9 \mathrm{mM}^{-\mathrm{CaCl}_{2}}$ and then begins to decline as the calcium ion con- 
centration is further increased above normal in either artificial or natural sea water.

The addition of excess $\mathrm{Ca}^{2+}$ to filtered 'natural' sea water has a less adverse effect on sperm motility than does the addition of excess calcium to ASW, but even in filtered sea water motility begins to decline when the calcium ion concentration is increased to twice its normal value (Text-fig. 1). Barron, Gasvoda \& Flood (1949) reported that ASW does not support sea urchin sperm motility as well as does 'natural' sea water which may contain protective substances in trace amounts.

The ability of EGTA drastically to reduce the swimming speed of dilute suspensions of Arbacia spermatozoa indicates that a critical amount of calcium must be necessary for optimum motility. Whether calcium exerts control of the contractile process through sites at the membrane or by its effects on cell metabolism, e.g. ATP synthesis, has not yet been determined.

The chelator, EDTA, sustains the motility of Arbacia spermatozoa at somewhat higher rates than equimolar concentrations of EGTA. This is probably due to the fact that EDTA interacts with magnesium as well as with calcium while EGTA interacts preferentially with calcium and there is approximately five times as much $\mathrm{Mg}^{2+}$ as $\mathrm{Ca}^{2+}$ in Woods Hole sea water (Cavanaugh, 1956). More EDTA than EGTA may therefore be required to reduce the calcium ion concentration to a level below that critical for sustained motility. Reduction of the $\mathrm{Ca}^{2+}$ content about tenfold below normal either by washing the spermatozoa in Ca-free sea water or by titration in EDTA or EGTA (about $1 \mathrm{mmol} / \mathrm{l}$ ) almost abolishes sperm motility.

The lanthanum ion, which acts by interfering with calcium movements across cell membranes that normally undergo increased calcium conductance during excitation (Van Breeman \& De Weer, 1970; Miledi, 1971; Van Breemen, Farinas, Gerba \& McNaughton, 1972), is an even more potent inhibitor of sea urchin sperm motility than EGTA and EDTA. Concentrations of lanthanum as low as $100 \mathrm{~nm}$ adversely affect Arbacia sperm swimming speed (Text-fig. 3). At a concentration of $20 \mu \mathrm{M} \mathrm{La}{ }^{3+}$, the spermatozoa become immotile and their flagella can be seen microscopically to be in a highly coiled state intertwined in large clumps. Lanthanum begins to exert its effects at concentrations about three orders of magnitude lower than either EDTA or EGTA. We may speculate that lanthanum competes with calcium for attachment to specific membrane sites or that lanthanum itself binds allosterically at membrane sites altering the physical or chemical characteristics of the membrane. Reversible release of calcium from sequestration in membrane loci appears to be responsible for the control of enzyme activity or for the initiation and control of the interaction of the contractile components of the sea urchin sperm flagellum. By blocking either $\mathrm{Ca}^{2+}$-release or -binding, lanthanum acts more powerfully than the chelating agents which appear to combine with $\mathrm{Ca}^{2+}$ stoichiometrically, the possibility that $\mathrm{La}^{3+}$ may prevent ATP depletion is suggested by the 'relaxed' appearance of the sperm flagella.

Using motility as an index of the metabolic and structural status of Arbacia punctulata spermatozoa, the present report shows that critical levels of calcium ions must be maintained and that intracellular levels apparently depend 
critically on the calcium ions present in the environment for optimum motility. In contrast, however, to the biphasic dose-dependent effects of other divalent cations (Young \& Nelson, 1974) and of neurochemical agents (Nelson, 1972), changing the $\mathrm{Ca}^{2+}$ concentration does not increase sperm motility above the control level.

\section{AGKNOWLEDGMENTS}

This work was partially supported by NIH Research Grants HD06491-02 and HD03266-05.

\section{REFERENCES}

Barron, E. S. G., Gasvoda, B. \& Flood, V. (1949) Studies on mechanisms of action of ionizing radiation. IV. Effect of X-ray irradiation on the respiration of sea urchin sperm. Biol. Bull. mar. biol. Lab., Woods Hole, 97, 44.

Barron, E. S. G., Nelson, L. \& Ardao, M. (1948) Regulatory mechanisms of cellular respiration. II. The role of soluble sulfhydryl groups as shown by the effect of sulfhydryl reagents on the respiration of sea urchin sperm. F. gen. Physiol. 32, 179.

Bredderman, P. J. \& Foote, R. H. (1971) The effect of Ca ions on cell volume and motility of bovine spermatozoa. Proc. Soc. exp. Biol. Med. 137, 1440.

BRoxAw, G. J. \& BENEDICT, B. (1968) Mechanochemical coupling in flagella. I. Movement-dependent dephosphorylation of ATP by glycerinated spermatozoa. Archs Biochem. Biophys. 125, 770 .

Cavanaugh, G. M. (Ed.) (1956) Formulae and Methods V of the Marine Biological Laboratory Chemical Room, p. 84. Marine Biological Laboratory, Woods Hole, Massachusetts.

Ebashi, S. (1972) Ga ions and muscle contraction. Nature, Lond. 240, 217.

Heilbrunn, L. V. \& Wiercinski, F. J. (1947) Action of various cations on muscle protoplasm. F. cell. comp. Physiol. 29, 15.

Kung, G. \& NaItoh, Y. (1973) Calcium-induced ciliary reversal in the extracted models of "Pawn," a behavioral mutant of Paramecium. Science, N.Y. 179, 195.

Lardy, H. A. \& Phillips, P. H. (1943) Effect of $\mathrm{pH}$ and certain electrolytes on the metabolism of ejaculated spermatozoa. Am. F. Physiol. 138, 741.

MaGrady, A. V. \& Nelson, L. (1972) The relationship between sperm cell biopotentials and the control of calcium movements. Proc. 5th Int. Congr. Pharmac., San Francisco, Calif. Abstr. No. 919, p. 154.

ManerY, J. F. (1969) Galcium and membranes. In Mineral Metabolism, Chap. 6, pp. 405-452. Eds. C. F. Cormar and F. Bronner. Academic Press, New York.

MiLEdi, R. (1971) Lanthanum ions abolish the "Ga response" of nerve terminals. Nature, Lond. 229, 410.

Murakami, A. \& Eckert, R. (1972) Gilia: activation coupled to mechanical stimulation by calcium influx. Science, N.Y. 175, 1375.

Nelson, L. (1972) Quantitative evaluation of sperm motility control mechanisms. Biol. Reprod. 6, 319.

ROTHSCHILD, LORD \& TUFT, P. H. (1950) The physiology of sea-urchin spermatozoa. The dilution effect in relation to copper and zinc. 7. exp. Biol. 27, 59.

ROTHSCHILD, LORD \& Tyler, A. (1954) The physiology of sea-urchin spermatozoa. Action of versene. F. exp. Biol. 31, 252.

Quinn, P. J., White, I. G. \& Voglmayr, J. K. (1970) Use of a continuous flow dialysis apparatus to determine the effects of cations, buffers and osmotic pressure on ram spermatozoa. F. Reprod. Fert. 22, 253.

Tyler, A. (1953) Prolongation of life-span of sea urchin spermatozoa and improvement of fertilizationreaction, by treatment of spermatozoa and eggs with metal-chelating agents (amino acids, versene, DEDTC, oxine, cupron). Biol. Bull. mar. biol. Lab., Woods Hole, 104, 224.

VAN BREemen, C. \& De WeER, P. (1970) Lanthanum inhibition of calcium efflux from the squid giant axon. Nature, Lond. 226, 760.

Van Breemen, C., Farinas, B. G., Gerba, P. \& MaNaughton, E. D. (1972) Excitation-contraction coupling in rabbit aorta studied by the lanthanum method for measuring cellular $\mathbf{C a}$ influx. Circulation Res. 30, 44.

Young, L. \& Nelson, L. (1974) The effects of heavy metal ions on the motility of sea urchin spermatozoa. Biol. Bull. mar. biol. Lab., Woods Hole, 147, 236. 